\title{
AFRICA AND THE DECLINE OF THE DEMOCRACY DEBATE
}

\author{
MOHAMED SALIH
}

PHD IN ECONOMICS AND SOCIAL SCIENCE, UNIVERSITY OF MANCHESTER, UK EMERITUS PROFESSOR OF POLITICS OF DEVELOPMENT AT THE INTERNATIONAL INSTITUTE OF SOCIAL STUDIES OF ERASMUS UNIVERSITY ROTTERDAM IN THE NETHERLANDS MSO1011952@CMAIL.COM

The debate on the decline of democracy is not new. It can be traced to the period between the First and Second World Wars, and it resurfaced during the 1970s, followed by the most spectacular democratic resurgence in human history. This lecture focuses on the current debate on the decline of democracy and downward trends in major democracy assessment indices. Africa is among the three least democratic world regions, with $42 \%$ of African countries currently designated as not free.

Measuring the decline or rise of democracy only by the performance of institutional politics does not provide a complete picture of the issue. Institutional politics does not account for the resilience and thriving new spaces where democratic vibrancy and civic engagement prevail. Examples from African countries demonstrate that democracy indices based on institutional politics alone do not account for alternative democratic spaces and practices.

This paper is the edited version of the keynote speech delivered by the author at the 6th Pécs African Studies Conference under the theme "African Realities: Conflict and Cooperation", September 23-24, 2021 - University of Pécs, Hungary.

Keywords

democracy, African state, governance, patrimonialism, deliberation 


\section{Introduction}

The decline of democracy is also referred to as democratic recession, democracy in retreat, democratic crisis, democratic discontent, democracy under siege, and democracy backsliding. Although all these connotations allude to different qualities of the decline, they all point to what they perceive as something terribly wrong that has happened to the democratic tradition post-Cold War order. A synoptic characterization of what we mean by democracy in decline is a crisis of the legitimacy of the state and its inability to protect fundamental freedoms, including respect of the rule of law, free and fair elections, minority rights, and freedom of the media. Such a depiction of the state of democracy would suggest that state institutions represented by governments have become dysfunctional, defined by cronyism and corrupt politicians supported by the equally corrupt political elite. This imprisonment of state institutions is reinforced by non-responsive elected representatives, who, in many cases, side with those who have overtaken the state rather than the people who elected them. In a sense, the decline of democracy is a symptom of the crisis of state legitimacy.

Therefore, it is not difficult to argue that by claiming that the crisis is a crisis of democracy, the state and the corrupt politicians attempt to shift the blame from the substance to the practice of democracy, which they have jeopardized. However, does the conflation of the decline of democracy and the crisis of state legitimacy mean that politics exists only in the state realm, or does the decline of the democratic values exercised within institutional politics suggest no other space for civic engagement exists? These questions inform the argument of this presentation. But before answering them, let me answer several preliminary questions: Is the debate on the decline of democracy new, and what makes it different this time? Why is democracy declining? How are citizens responding to the double crisis of the state and democracy?

\section{Is the debate on the decline of democracy new?}

The decline and even the end of democracy themes are not new. The debate on the end of democracy raged between the First and Second World Wars, appearing in Ralph Adam Cram's 1937 book The End of Democracy. ${ }^{1}$ He argued that the end of democracy was already taking place (1937: 19). For Cram (Ibid. 1937: 10), the end of democracy began with the emergence of three totalitarian regimes: First, a communist system under Stalin, who in effect created state capitalism under the dictatorship of the proletariat; second, the supreme tyranny of a self-perpetuating oligarchy under the dictatorship of Hitler and Nazism;.third, fascism proclaimed "all for the state, nothing outside the state, nothing against the state" (Sternhel 1976: $356)^{2}$, leaving no space for civic engagement or democratic practices.

Cram's concerns are understandable as the period between the two World Wars did not give much room for optimism, considering the rise of fascism and nazism in Europe. But democracy did not die and it rebounded after the Second World War, becoming the only game in town despite its ups and downs.

About three decades after Cram pessimistic book, Crozier, Huntington and Watanuki (1975) were entrusted by the U.S. Government to lead the work of the Tri- 
lateral Commission on the governability of democracy. The Trilateral Commission was established to respond to a perceived decline of democracy in the USA, Europe, and Asia. The report was prudent enough to ask the question as to whether political democracy as it existed during the mid-1970s was a viable form of government for the industrialized countries of Europe, North America, and Asia. The commission concluded that it wasn't because representative democracy and its institutions required significant reforms to establish a more viable system of government for the $20^{\text {th }}$ century. ${ }^{3}$

Today, the same question is posed with increasing urgency by intellectuals, the general public, and media outlets. It is being reflected in public opinion polls and democracy indicators. John Kean's (2009) ${ }^{4}$ seminal work The Life and Death of Democracy captured these themes, tracing the rise and fall of democracies and empires from the early history of civilizations and empires. He also documented the most recent global expansion of representative democracy from Europe. Kean laments that representative democracy alone is no longer capable of satisfying citizens' craving for new forms of democracy, mainly drawn from the current democratic development worldwide.

Keane's proclamations of the near-death of representative democracy were picked up by democracy assessment indices depicting what is now referred to as the decline of democracy. Two influential journals published special issues on the theme:

Foreign Affairs (2015), ${ }^{5}$ a journal considere the best in the business for unlocking future political trends and informing policies and decision-makers, followed suit with a special issue titled Democracy in Decline and How Can Washington Reverse the Tide? Larry Diamond (2015) stated that "Democracy itself seems to have lost its appeal," adding that "many emerging democracies have failed to meet their citizens' hopes for freedom, security, and economic growth, just as the world's established democracies, including the United States, have grown increasingly dysfunctional." ${ }^{6}$ Fukuyama (2015: 11) asked an important question: "Why is democracy performing so poorly?" He questioned whether we are experiencing a momentary setback in a general movement toward greater democracy worldwide or whether this signals a broader shift in world politics and the rise of alternatives to democracy. The Journal of Democracy (2016) released a special issue with the theme Is Democracy in Decline?, which was edited by Larry Diamond and Marc Plattner. The contributors to this special issue are considered some of the world's leading scholars and policymakers in the field of democracy promotion and assessment, including Francis Fukuyama, Robert Kagan, Marc F. Plattner, Larry Diamond, and Thomas Carothers.? 
It is plausible to argue that debates about the decline of democracy are not new. Democratic decline is associated with the crisis in state legitimacy and democratic institutions becoming dysfunctional. For example, between the two wars when Crams wrote about the end of democracy, in the 1970s the Trilateral Commission was set up during the Watergate cover-up, the U.S. defeat in Vietnam, the civil rights movement and racial conflicts, and economic decline. It is not surprising that the decline debate begun during the Trump Presidency that epitomized the tarnished image of U.S. democracy during the second decade of the $21^{\text {st }}$ century. ${ }^{8}$

However, there are differences and similarities. First, earlier periods of the decline of democracy were confined to the USA and Europe as most developing countries, including Africa, were still under colonial rule. Democracy was the privilege of the colonial powers, which preserved democratic values for their citizens, while no such privileges were accorded to the colonized. Colonial rule was neither democratic nor respectful of the human rights of citizens in the colonies.

The common denominator of the decline of democracy is global. This time around, the crisis of democracy is affecting the world globally, including Africa. The factors explaining this decline are not only relevant to Africa but also global. Plattner (2015:7) mentioned three of these factors: 1) the growing sense that the advanced democracies are in trouble in terms of their economic and political performance; 2) the new self-confidence and seemingly apparent vitality of some authoritarian countries, and 3) the shifting geopolitical balance between democracies and their rivals. ${ }^{9}$ Likewise, Thomas Carothers noted that democracy's tavails or backsliding in both the United States and Europe have significantly damaged the standing of democracy in the eyes of many people around the world. For example, the flip side of democracy's dwindling standing has been the growing clout of several leading authoritarian regimes. Key among them is China, whose ability to make enormous economic strides without introducing democratic reforms has cast doubt on the notion that democracy is the only appropriate political system for wealthy countries (Carothers 2015:5). ${ }^{10}$

Conventionally, the failure of African democracy was explained against the backdrop of factors such as the politics of the belly ${ }^{11}$, patrimonialism, lack of social and cultural embeddedness, and religious and ethnic cleavages. However, these factors existed prior to the latest decline of democracy and, therefore, was not expected to intensify over the last decade or so. These factors may point more to the intensity of the crisis of state legitimacy rather than factors inherent in the internal dynamics ofAfrican society and culture. Regardless of what factors have induced the worldwide decline of democracy, these factors have nothing to do with African culture and society as sources of current democratic decline.

\section{How Does Africa Fare in The Debate?}

During 2010-2019, Africa was rated as the third world region with the highest percentage of countries where democracy had declined (41\%), which was far above the world average (28\%) for non-democratic countries (Table 1 and Figure 1) (Freedom 
in The World 2021: 20-26) ${ }^{12}$. The free and partially-free countries in Africa comprise $59 \%$, a decline from about $61 \%$ in $2000 \cdot{ }^{13}$ Among the 15 countries with the highest declining democracies, Mali, Tanzania, Burundi, Benin, Mozambique, Comoros, Gabon, and Uganda have seen the highest decline during the last ten year, ranging between $-39 \%$ in Mali and $-11 \%$ in Uganda - with the other five countries falling between Mali and Uganda.

Ibrahim Index of African governance (2020) produced similar results (Table 2 and Figure 2), but with far less negative score change for security and the rule of law $(-0.7 \%)$ and participation, rights, and inclusion $(-1.4 \%)$. When the score change between. 2010-2019 for the foundation of economic opportunity $(+4.1 \%)$ and human development $(+3.0 \%)$ is added, the overall African average was $+1.2 \%$.

\begin{tabular}{l|c|c|c}
\hline \multicolumn{1}{c|}{ Region } & Free (\%) & Partly Free (\%) & Not Free (\%) \\
\hline Americas & 60 & 31 & 9 \\
\hline Asia Pacific & 44 & 33 & 23 \\
\hline EURASIA & 0.0 & 33 & 67 \\
\hline Europe & 81 & 17 & 2 \\
\hline Middle East and North Africa & 11 & 17 & 72 \\
\hline Sub-Saharan Africa & 16 & 43 & 41 \\
\hline World Average & 42 & 30 & 28 \\
\hline
\end{tabular}

^ Table 1. World average and regional classification by category and scores (\%), 2020.

Source: Freedom in the World Report, 2021, available at: https://freedomhouse.org/report/freedom-world/2021/democracy-under-siege

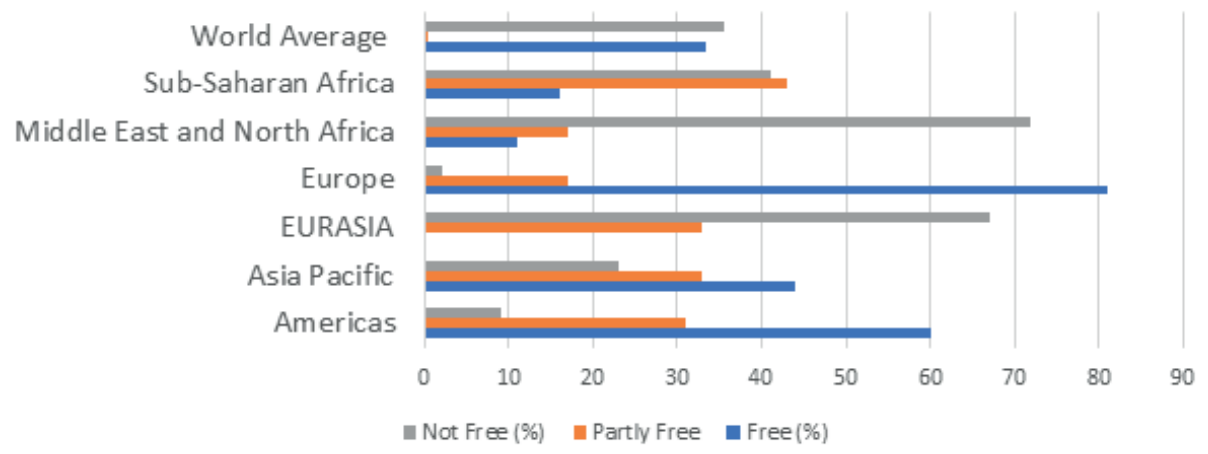

^ Figure 1: World and regional classification by category (\%), 2020.

Source: Freedom House (2021). Freedom in the World Report, available at: https://freedomhouse. org/report/freedom-world/2021/democracy-under-siege

Mohamed Salih: Africa and the decline of the democracy debate 


\begin{tabular}{l|c|c}
\hline \multicolumn{1}{c|}{ Trend classification } & 2019 average score & Score change 2010-2019 \\
\hline Security and Rule of Law & 49.5 & -0.7 \\
\hline Participation, Rights and Inclusion & 46.2 & -1.4 \\
\hline Foundations for Economic Opportunity & 47.8 & +4.1 \\
\hline Human Development & 51.9 & +3.0 \\
\hline Overall African Governance Average & 48.8 & +1.2 \\
\hline
\end{tabular}

^ Table 2. African governance trend Classification, 2019 average and 2010-2019 score change. Source: Ibrahim Index of African Governance, 2021, available at: https://mo.ibrahim.foundation/ sites/default/files/2020-11/2020-index-report.pdf

Four conclusions can be made from the findings of Freddon in the World and Ibrahim Index of African Governance:

1. The indices are state-centric, focusing on how citizens' rights are disregarded or not guaranteed, respected or acted upon as codified in the jurisdictions of the legislative state. The indices inform us that the state has failed to discharge its duties of facilitating and reinforcing democratic rules, but has instead flouted the rules.

2. There is a priori assumption that institutional politics and organized civic associations are the only spaces where democracy is practised, thus ignoring the pervasive nature of politics permeating the totality of human activities and existence.

3. Those who claim that democracy has declined assume that institutional democracy and conventional representative democracy are the only spaces for democratic expression.

4. Even if the claim that democracy is declining is true, the introductory remarks have shown that upward and downward trends in democratic performance are not new. Therefore, it should not come as a surprise that crises are common to democracy, particularly during periods of state capture ${ }^{14}$, extreme economic and political corruption, minority exclusion, dereliction of duty, abuse of office, and economic recession.

With these four conclusions in mind, the final part of this presentation is devoted to Africa's new and expanding spaces and forms of democracy outside institutional politics.

\section{New spaces and forms of democracy are expanding}

Four developments characterize the past two decades of democratic resurgence outside institutional politics: local and grassroots democracy, cyber democracy, and the expansion of private, political party and interest groups TV and radio brodcasters, including digital radios. 


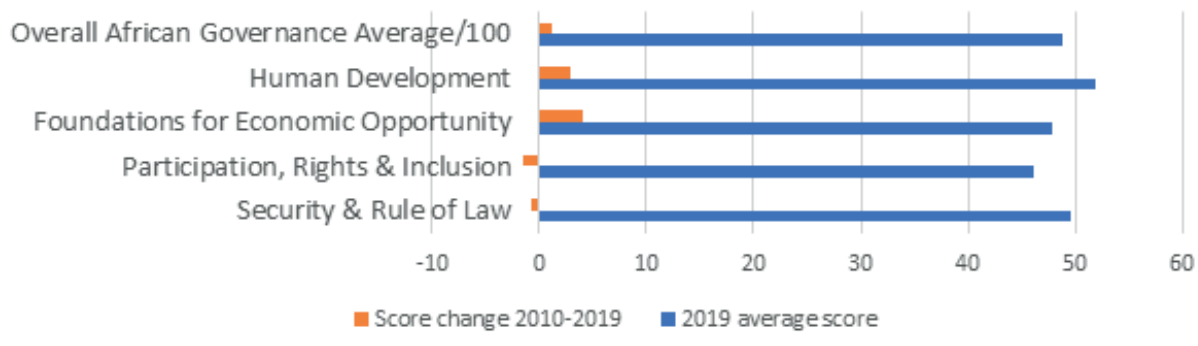

^ Figure 2: Trend Classification, 2019 and 2010-2019 score change (\%).

Source: Ibrahim Index of African Governance, 2020, available at: https://mo.ibrahim.foundation/ sites/default/files/2020-11/2020-index-report.pdf

First, voter turnout is not linear, and booms and busts are part of the democratic process. Large voter turnout could be attributed to many factors. Some are related to regulations, such as when there is more voters turnout in countries with compulsory voting. There is documented evidence of higher voter turnout in authoritarian regimes where party leaders intimidate citizens into voting against their will. In transition or mature democracies, low voter turnout is not necessarily an indicator of the quality of the democratic process. Even in old democracies, legal trickery was used to exclude a disfranchised population, such as African Americans in the United States. Low voter turn out could be attributed to political exclusion and lack of government response to citizens' fundamental socio-economic concerns, where state capture and patronage are rampant. The assumption that low voter turnout is a sign of apathy should not be understood to mean that citizens cannot relocate their political energy to where politics matter.

Second, there has been an emergence of politically active and expanding local and grassroots deliberative democracies. In 2015, it was estimated that local government political executives were elected in $80 \%$ of the African countries where more than $60 \%$ of the population lives..$^{15}$ Local government authorities and elected legislatures exhibited better transparency, citizen participation, and democratic and legislative practices than central government institutions. This vast space of local democratic practices should be treated as one of the primary outcomes of democratization that began in the early 1990s. However, it is not apparent that democracy indices include deliberative democracies performed at the local level and among this critical section of the African population.

During the 1990s, the near breakdown of public service institutions in some African countries compromised state legitimacy and its role as provider of public amenities (health, education, water and sanitation, etc.). After the resurgence of democratic development, most African states lost control of national public policy due to incapacity or lack of resources to fulfil their responsibilities as functioning states. 
It is estimated that over 45 African countries' local governments have embarked on reforms aiming at decentralizing and devolving service delivery functions to the local authorities since 1990. Some of the local government reforms codified laws that recognize chieftainships as part of local governance. Efforts to hold the government accountable have shifted to include the new generation of social accountability practices that emphasize a solid evidence base and direct dialogue and negotiation with government outside the established local governance networks. Adopting such immediate deliberations instead of conventional democracy, including demonstrations, protests, or antagonising government institutions, does not make these democratic practices less democratic.

Democratic spaces for civic engagement have expanded following rural and urban local communities withdrawal from state-created democratic political spaces to community and indigenous forms of direct deliberations. Citizens deliberately forming groups to solve fundamental social and political problems confronting local communities are not new to Africa. For example, endogenous and modern local institutions co-exist in Ghana, Kenya, Malawi, Zambia, Botswana, Mozambique, Rwanda, and South Africa. They often develop joint collaboration and they benefit from each other's leverage.

Deliberation at the local level is not only about service delivery. It is also about local politics, local elections, and the aspiring political elite who flock to the countryside during national elections. Local political party representatives, candidates, and agents hold more primaries and debates than those organized at the national capitals. Youth, women, farmers, pastoralists, traders, and nongovernmental and civil society organizations regularly participate in deliberations to resolve local problems, such as
It is estimated that over 45 African countries' local governments have embarked on reforms aiming at decentralizing and devolving service delivery functions to the local authorities since 1990. Some of the local government reforms codified laws that recognize chieftainships as part of local governance. Efforts to hold the government accountable have shifted to include the new generation of social accountability practices that emphasize a solid evidence base and direct dialogue and negotiation with government outside the established local governance networks. 
water, health, education, and forestation. In most cases, such community deliberation includes like-minded transnational NGOs and democracy activists.

Suppose proclamations about the decline of democracy are to be trusted. In that case, they should go beyond the current data craze and engage the emergent new forms of local, community, and grassroots deliberations where the majority of the World population practice democracy locally. This type of grassroots deliberations have been taking place for decades and expanding in Africa and the rest of the developing world. Therefore, the gatekeepers of democracy dismiss local community and grassroots deliberations as non-existent while representing the spaces where authentic people-centred politics occurs.

Third, there is an expanding role of social media and cyberdemocracy. Since the late 1990s, the rapid expansion and convergence of information and communication technologies have created new spaces for political engagement, which has expanded citizens' freedom to exchange information, organize political action and social movements, and rediscover the growth of a new vocabulary of resistance. While democracy's essential values have persisted, the forms and spaces of democratic practices have multiplied. Consider, for example, e-government, e-political parties, e-parliaments, and e-civic networks and associations, all of which have become prominent features for citizens not only for accessing information but also for using information to make governments more responsive.

The emergence of local, national, regional and globally networked interest groups using social media to debate social issues of great significance online has ushered in an era of unprecedented global interaction. These virtual communities engage institutional politics and include grassroots organizations, social movements, opposition parties, women and youth. They are supported by like-minded political party members, traders, innovators, indigenous movements, and religious denominations.

Fourth, there has been an expansion of private TV and radio broadcasting for cyber democracy and political mobilization. In 2000, it was estimated that there were 600 TV broadcasters in Africa. ${ }^{16}$ This number rose to about 1500 in 2020. Most of these broadcasters are private, with the government (or public) broadcasting corporations facing stiff competition from the national and international TV broadcasters. In 1990, about 120 radio stations in Africa were public, with a few operating under strict state surveillance. In 2020, the number increased to over 4500 radio stations. The majority are digital, using computer-mediated communication. ${ }^{17}$ Most FM radios have parted with the use of foreign languages to broadcasting in national or local languages. The use of new media such as YouTube and Facebook to challenged digital TV and radio broadcasting, reducing the African government's capacity to restrict the flow of information and freedom of expression.

Political parties and public interest groups (environment, religion and women) use private TV and radio media to spread their political, social, and cultural messages. Political parties envisage their broadcasting outlets to subvert the state monopoly 
over the media, particularly in the build-up to national and local elections. Radio use as a source of information is still prevalent in rural Africa, where fewer than $10 \%$ of the population has access to TVs and computers, with around $6 \%$ having internet access. $^{18}$

In short, the expansion of private radio broadcasting, digital radios, private print and electronic newspapers, and TV stations have broken the state monopoly over information and its capacity to hinder political competition. Long gone are the days when the state-owned radio and TV stations and print newspapers were the only sources of information about the political programmes of competing political parties. Cyber democracy is one of the foremost enablers of freedom of information, the most cherished pillar of democracy. In Campbel (2018) words, there are three ramifications of cyber-democracy:

1. The networking opportunities and capabilities of interaction and communication increase;

2. The volume of codified knowledge cumulates, and the possibilities to publicly access this knowledge also improve; and

3. Digitalized information and knowledge, and the Worldwide Web, created a network-style and infrastructure of knowledge, allowing a knowledge conversion of the local into the global and vice versa. ${ }^{19}$

On the other hand, it has also become a norm that authoritarian and sem-authoritarian regimes block the internet and withdraw private and political party media outlets' licenses. Such exclusionary methods emphasize the significance of the new media's role in creating new spaces for political engagement.

\section{Conclusions}

Democracy is expanding into new spaces and taking new forms complementing rather than replacing representative democracy. The modest gains or presumed decline of democracy can be attributed to citizens' relocation of their democratic energies to these new spaces and local deliberative democracies. Rather than retreating, democracy has exhibited considerable resilience.

Crams declared the end of democracy in 1937 between the two World Wars. Huntington and associates declared the crisis of democracy in 1975 during the height of the Watergate scandal, The latest crisis in American democracy was during the Trump presidency. All these periods of democratic decline occurred during times characterized by a crisis of state legitimacy.

Therefore, it is plausible to conclude that the moment the state, the cronies of the state and the self-serving political elite are made to shape their relationship with citizen's, democracy will rebound. If the state is restructured to serve citizens' interests and become responsive to their legitimate demands, we would certainly be rejoycing in the rebirth of democracy. 


\section{Notes}

1 Cram, Ralph Adams 1937. The End of Democracy. Boston: Marshall Jones Company. $\mathrm{r}$

2 Sternhel, Zeev (1976). “Fascist Ideology in Walter Laqueur” (ed.) Fascism: A Reader's Guide: Analyses, Interpretations, Bibliography. Berkely and Los Angels: California University Press.

3 Crozier Michel, Samuel Huntington and Joju Watanku 1975. The Crisis of Democracy - The Trilateral Commission. New York: New York University Press.

4 Keane, John 1999. The Life and Death of Democracy. Pocket Books: London, Sydney, New York and Toronto.

5 Diamond Larry (ed.) (2015). "Democracy in Decline: How Washington Can Reverse the Tide", in Foreign Affairs 95/4.

6 Diamond, Larry. 2015. "Democracy in Decline: How Washington Can Reverse the Tide". Editorial, in Foreign Affairs, 95/4. August/September Special Issue.

7 For these and other authors refer to Journal of Democracy (2015), 26/1.

8 Kruse, Kevin M. and Julian E. Zelizer. (2019). Fault Lines: A History of the United States Since 1974. New York: W. W. Norton and Company.

9 Plattner, Marc. F (2015). 'Is Democracy in Decline?' Journal of Democracy 26/1: 5-10.

10 Carothers, Thomas. (2015). "Democracy Aid at 25: Time to choose", Journal of Democracy 59-73.

11 Refers to patron-client relation, poverty as a factor undermining democracy or that politicians hore resources for themselves and their social support-base to the detrimant of the survival of the rest of the population.

12 The determination of free, partly-free and not-free is based on computing the indicators of seven variables: Political pluralism and participation, electoral process, personal autonomy and individual rights, associational and organizational rights, freedom of expression and belief, rule of law and functioning of government (Freedom House 2021).

13 A free country scores above 70 scores, partly free sore between 70 and 40 scores, not free countries score less than 40 scores in political rights and civil liberties.

14 State capture means the political elite and the business class join hands to capture the state through corrupotion and manipulation of the rules of the politial game.

15 UCLG. (2018). Assessing the Institutional Environment of Local Government in Africa. United Cities and Local Governments of Africa. Available at: https:/www.uclga.org/wpcontent/uploads/2018/02/Assessing_the_Institutional_Environment_of_LG_in_Africa.pdf [accessed 10 August 2021].

16 Eutelsat (2021). TV Viewing Trends In Sub-Sahara Africa, available at: https://www.eutelsat. $\mathrm{com} / \mathrm{en} / \mathrm{blog} / 6$-TV-viewing-trends-in-sub-saharan-africa.html [accessed 28 August 2021].

17 ITU (2020). Measuring digital development Facts and figures 2020. Geneva: International Communication Union (ITU): available at: https://www.itu.int/en/ITU-D/Statistics/Documents/facts/FactsFigures2020.pdf

18 Nwulu, Nnamdi I, Adeyemi Adekanbi, Tochukwu Oranugo, Yemi Adewale (2010) "2010 Second Region 8 Ieee Conference on the History of Communications," in Television Broadcasting in Africa: Pioneering Milestones, pp. 1-6. doi: 10.1109/HISTELCON.2010.5735315.

19 Campbell, David F. J. (2018). "Cyberdemocracy”, in Carayannis, Elias G., Campbell, David F. J., Efthymiopoulos, Marios Panagiotis (eds.). Handbook of Cyber-Development, CyberDemocracy and Cyber-Defense. Cham, Switzerland Springer, 113. 